\title{
Late-Onset Leanness in Mice with Targeted Ablation of Melanin Concentrating Hormone Neurons
}

\author{
Tamar Alon and Jeffrey M. Friedman \\ Laboratory of Molecular Genetics, The Rockefeller University, New York, New York 10021
}

The observation that loss of orexin (hypocretin) neurons causes human narcolepsy raises the possibility that other acquired disorders might also result from loss of hypothalamic neurons. To test this possibility for body weight, mice with selective loss of melanin concentrating hormone $(\mathrm{MCH})$ neurons were generated. $\mathrm{MCH}$ was chosen to test because induced mutations of the $\mathrm{MCH}$ gene in mice cause hypophagia and leanness. Mice with ablation of MCH neurons were generated using toxin (ataxin-3)-mediated ablation strategy. The mice appeared normal but, after 7 weeks, developed reduced body weight, body length, fat mass, lean mass, and leptin levels. Leanness was characterized by hypophagia and increased energy expenditure. To study the role of $\mathrm{MCH}$ neurons on obesity secondary to leptin deficiency, we generated mice deficient in both ob gene product (leptin) and $\mathrm{MCH}$ neurons. Absence of MCH neurons in ob/ob mice improved obesity, diabetes, and hepatic steatosis, suggesting that $\mathrm{MCH}$ neurons are important mediators of the response to leptin deficiency. These data show that loss of $\mathrm{MCH}$ neurons can lead to an acquired leanness. This has implications for the pathogenesis of acquired changes of body weight and might be considered in clinical settings characterized by substantial weight changes later in life.

Key words: MCH; ataxin; leanness; ablation; body weight; energy homeostasis

\section{Introduction}

In this study, we set out to test whether the loss of a specific hypothalamic cell population could lead to a late onset change in body weight by selectively ablating melanin concentrating hormone $(\mathrm{MCH})$ neurons in the lateral hypothalamus. $\mathrm{MCH}$, a neuropeptide expressed in the lateral hypothalamus and zona incerta, plays an important role in complex motivated behaviors, including the regulation of energy homeostasis (Qu et al., 1996; DiLeone et al., 2003; Verret et al., 2003). The diverse functions of $\mathrm{MCH}$ are mediated by two G-protein-coupled receptors, MCH-R1 and MCH-R2 (Chambers et al., 1999; Hill et al., 2001). MCH neuropeptides are derived from a larger prohormone precursor, which also encodes other putative neuropeptides including EI, neuropeptide GE, MCH gene overprinted polypeptide, and antisense RNA overlapping $\mathrm{MCH}$ (Bittencourt et al., 1992; Toumaniantz et al., 1996; Borsu et al., 2000). The biological role of these additional neuropeptides is not fully established.

Several studies have established $\mathrm{MCH}$ as an important regulator of feeding behavior. It has been shown that the expression

Received March 28, 2005; revised 0ct. 24, 2005; accepted 0ct. 25, 2005.

This work was supported by National Institutes of Health-National Institute of Diabetes and Digestive and Kidney Diseases Grant DK041096-14. We thank Dr. M. Yanagisawa for providing us with the ataxin-3 cassette; Drs. N. Heintz, K. Losos, and S. Gong from the Gene Expression Nervous System Atlas BAC Transgenic Project at the Rockefeller University for their assistance in the MCH/ataxin-3 BAC microinjection; Dr. T. Maratos-Flier for providing us with MCH antibodies; $C$. Hunter for assistance with the initial liver histology; $X$. Cai for technical assistance; $G$. Fayzikhodjeava for assistance with the leptin treatment; M. Hogan for technical assistance; J. Mansfield for critical reading of this manuscript and assistance with the technology; and $S$. Korres for administrative assistance in preparing this manuscript. We declare that we have no compelling financial interest.

Correspondence should be addressed to Jeffrey M. Friedman, The Rockefeller University, 1230 York Avenue, New York, NY 10021. E-mail: friedj@rockefeller.edu.

DOI:10.1523/JNEUROSCI.1203-05.2006

Copyright $\odot 2006$ Society for Neuroscience $\quad$ 0270-6474/06/260389-09\$15.00/0 level of MCH mRNA increases in leptin-deficient obese (ob/ob) mice as well as in response to fasting in wild-type mice (Qu et al., 1996). It is also been shown that intracerebroventricular administration of $\mathrm{MCH}$ causes a rapid increase in food intake (hyperphagia) and obesity (Gomori et al., 2003). Genetic models further confirm the role of $\mathrm{MCH}$ in energy homeostasis. Mice lacking the MCH1-R are lean, hyperactive, hyperphagic, and hypermetabolic (Chen et al., 2002). The ablation of the prepro$\mathrm{MCH}$ gene lead to leanness in wild-type mice and an attenuation of the obese phenotype in leptin-deficient ob/ob mice (Shimada et al., 1998; Segal-Lieberman et al., 2003), whereas the mice that overexpressed the prepro-MCH gene exhibited obesity and insulin resistance (Ludwig et al., 2001).

The cellular and axonal distribution of the $\mathrm{MCH}$ system is also consistent with a role in energy homeostasis regulation. $\mathrm{MCH}$ is predominantly expressed in the lateral hypothalamic area, a region implicated in feeding behavior (Guan et al., 2002). MCH neurons make monosynaptic projections throughout the brain to a wide variety of structures that are known to participate in feeding (Zamir et al., 1986). MCH receptors are also expressed in the hypothalamic areas implicated in the control of energy homeostasis such as the ventromedial, dorsomedial, and arcuate nucleus (Kokkotou et al., 2001).

Although mutations in the $\mathrm{MCH}$ gene alter body weight, these studies have not allowed an assessment of the broader role of $\mathrm{MCH}$ neurons. In addition to $\mathrm{MCH}$, the neurons also express classical neurotransmitters and potentially other neuropeptides. To ablate these neurons, we used a toxin-mediated genetic cell ablation strategy using a truncated Machado-Joseph disease gene product (ataxin-3) under the control of an $\mathrm{MCH}$ promoter. The ataxin-3 transgene has been used to induce apoptosis in cells in vitro and for the ablation of orexin neurons in vivo (Yoshizawa et 
al., 2000; Hara et al., 2001). As described below, the ablation of $\mathrm{MCH}$ neurons results in significant weight loss developing later in life.

\section{Materials and Methods}

Animal care. All mice were weaned at 3-4 weeks of age, genotyped, grouped, and housed according to gender. Mice were exposed to a standard $12 \mathrm{~h}$ light/dark cycle in a temperature-controlled room and fed ad libitum. C57BL/6J+/+ and FVB/n mice were purchased from The Jackson Laboratory (Bar Harbor, ME). Genotypes were determined by the PCR amplification of genomic DNA. All procedures were in accordance with the guidelines set forth by The Rockefeller University Laboratory Animal Research Center.

Generation of MCH/ataxin-3 transgenic mice. The MCH/ataxin-3 transgenic mice were created using bacterial artificial chromosome (BAC) transgenic technology (Yang et al., 1997). The MCH/ataxin-3 construct contained an ataxin- 3 transgene under the control of a mouse $\mathrm{MCH}$ promoter and the $\mathrm{N}$ terminus of the $\mathrm{MCH}$ gene. Dr. M. Yanagisawa (University of Texas, Dallas, TX) provided us with an ataxin-3 transgene cDNA. The ataxin-3 transgene is a cDNA fragment of human ataxin-3 gene with 77 polyglutimine repeats that encodes from amino acid 286 to the $\mathrm{C}$ terminus. The human ataxin-3 gene was isolated from a patient with Machado-Joseph disease (Paulson et al., 1997). The N terminus of the ataxin-3 transgene contained hemagglutinin (HA) epitope. The $\mathrm{C}$ terminus of the transgene contained a myelocytomatosis oncogene (MYC) epitope (Invitrogen, San Diego, CA) that was followed by a murine protamine 1 -gene fragment $(\mathrm{mPrm} 1)$. The $\mathrm{mPrm} 1$ fragment (which included part of exon 1, intron 1, and exon 2) provided an intron and polyadenylation signal (Hara et al., 2001). The ataxin-3 transgene was introduced to the ATG site of the MCH BAC using a homologous recombination-based method. The modified MCH BAC contains $76 \mathrm{~kb}$ of a $5^{\prime}-\mathrm{MCH}$ sequence, followed by the ataxin-3 transgene. BAC filters (BAC mouse II) were obtained from Genome Systems (St. Louis, MO). We cloned the $\mathrm{MCH} /$ ataxin-3 construct into the shuttle vector PSV1 for the BAC modification. The PSV1 shuttle vector has a temperaturesensitive origin of replication, recombination RecA gene (which introduces recombination in a recombination-deficient Escherichia coli host), and tetracycline resistant gene (Tet+). The shuttle vector has $76 \mathrm{~kb}$ upstream and $97 \mathrm{~kb}$ downstream arms of $\mathrm{MCH}$ sequence flanking the ataxin-3 on both sides. The shuttle vector was transformed into a DH10B E. coli host, which harbored the MCH BAC. After two homologous recombination events, the modified MCH BAC was selected based on temperature and antibiotic sensitivity. The homologous recombination of the modified BAC was confirmed through Southern blot analysis. The transgenic founder lines were generated by microinjecting BAC DNA purified with a cesium chloride gradient into the pronucleus of fertilized oocytes from an FVB/n strain using the Gene Expression Nervous System Atlas BAC Transgenic Project at the Rockefeller University transgenic facility. Founder animals were mated with FVB/n mice to generate F1 mice, which were used for the characterization. The presence and copy number of the transgene was determined by Southern blot and PCR analysis of the tail genomic DNA. Five transgenic lines were established. To explore the role of $\mathrm{MCH}$ neurons in an ob/ob phenotype, we generated a mouse model deficient in both leptin and $\mathrm{MCH}$ neurons. We intercrossed $\mathrm{C} 57 \mathrm{BL} / 6 \mathrm{~J} \mathrm{ob} /+$ (The Jackson Laboratory) and $\mathrm{FVB} / \mathrm{n}$ $\mathrm{MCH} /$ ataxin-3 mice, which generated $\mathrm{MCH} /$ Ataxin-3/ob/+ (F1) mice with a mixed $\mathrm{C} 57 \mathrm{BL} / 6 \mathrm{~J}$ and $\mathrm{FVB} / \mathrm{N}$ genetic background. We also intercrossed $\mathrm{MCH} /$ Ataxin-3/ob/+ mice to generate $\mathrm{MCH} /$ ataxin-3/ob/ob (F2) mice. The ob gene was genotyped by PCR as described previously (Erickson et al., 1996).

Immunohistochemistry. Animals were anesthetized with isoflurane and perfused with $4 \%$ paraformaldehyde (PFA) in a PBS solution. Brains were postfixed in a $4 \%$ PFA solution for $24 \mathrm{~h}$. Brain sections $(50 \mu \mathrm{m})$ were obtained using a vibratome. Sections were incubated with a blocking solution ( $2 \%$ normal goat serum, $3 \%$ bovine serum, and $0.25 \%$ triton in PBS) for $1 \mathrm{~h}$ at room temperature. Then, the sections were incubated overnight at $4^{\circ} \mathrm{C}$ with primary antibodies. For the detection of $\mathrm{MCH}$ neurons, we used rabbit anti-MCH antibodies provided to us by Dr. T.
Maratos-Flier (Beth Israel Deaconess Medical Center, Boston, MA). For the detection of orexin neurons, we used rabbit anti-Hypocretin antibodies purchased from Oncogene Research Products (Cambridge, MA). For the detection of glia cells, we used rabbit anti-glial fibrillary acidic protein (GFAP) antibodies provided to us by Sigma (St. Louis, MO). For the double label immunohistochemistry (IHC), sections were incubated overnight with primary rabbit anti-MCH and goat anti-MYC (purchased from Santa Cruz Biotechnology, Santa Cruz, CA) antibodies in a blocking solution. Sections were rinsed three times with PBS for 10 min each and incubated with a secondary tetramethylrhodamine isothiocyanateconjugated goat anti-rabbit antibody and FITC-conjugated donkey antigoat (purchased from Jackson ImmunoResearch, West Grove, PA) in a blocking solution for $1 \mathrm{~h}$ at room temperature. The slides were examined under a Zeiss (Thornwood, NY) Axioplan fluorescence microscope with Zeiss AxioVision software. The software helped operate the microscope and acquire the sectional images.

Northern blot analysis. We used total hypothalamic RNA (10 $\mu \mathrm{g}$ per lane) for the Northern blot analysis. Following the instructions of the manufacturer, we used Trizol (Invitrogen) for RNA extractions. The RNA samples were fractionated by an agarose-formaldehyde gel electrophoresis and then transferred to nylon membranes using capillary transfer (Sambrook et al., 1989). The filters were incubated at $65^{\circ} \mathrm{C}$ in Ultrahyb (purchased from Ambion, Austin, TX) with a 1-mega count $/ \mathrm{min} / \mathrm{ml}$ ${ }^{32} \mathrm{PdCTP}-$ labeled DNA probe, which was amplified by PCR. Autoradiography was performed on the filters after they were washed with a highstringency solution.

Body weight, food intake, and body composition analysis. Body weights were measured once a week for group-housed mice on a regular diet. Food intake was measured in single caged mice after a 1 week period of acclimation. Body composition was used to determine total fat, lean, and water mass (Halaas et al., 1995). Carcasses were weighed and then oven dried in a $90^{\circ} \mathrm{C}$ oven until constant mass was achieved. Body water weight was determined by subtracting the differences in the weight of the carcasses before and after drying. The dried body was ground in a blender. Then, duplicate aliquots were extracted with a 3:1 mixture of chloroform to methanol using Soxhlet apparatus.

Metabolic rate and motor activity measurement. Metabolic rates and spontaneous motor activity was measured by using Oxymax and OptoM3 systems purchased from Columbus Instruments (Columbus, $\mathrm{OH})$. Animals were housed in calorimeter chambers individually and subjected to a $12 \mathrm{~h}$ light/dark cycle. Food and water were available in the chambers. Recording began $1 \mathrm{~d}$ after the mice were introduced to the chambers to give them time to acclimate. Consecutive IR beam breaks were scored as an ambulatory count. Cumulative ambulatory activity counts were monitored every minute for each IR beam break in three planes $(x, y$, and $z$ ) for three consecutive $24 \mathrm{~h}$ periods. Metabolic rates were calculated using a correction for weight.

Subcutaneous leptin treatment. Two weeks before the mice were treated with leptin, they were individually caged and had their food intake measured daily to establish an average baseline. Alzet 2002 mini-osmotic pumps with an exchange rate of $0.5 \mu \mathrm{l} / \mathrm{h}$ (Alza, Cupertino, CA) were filled with either a PBS solution (control group) or leptin (Amgen, Thousand Oaks, CA) at a concentration of $500 \mathrm{ng} / \mu \mathrm{l}$ (transgenic and wild-type leptin-treated groups) and implanted subcutaneously while under anesthesia. Food intake and weight were measured on a daily basis. After $9 \mathrm{~d}$, the osmotic pumps were removed, and food intake and body weight were measured daily for an additional $8 \mathrm{~d}$.

Neuroendocrine function. Blood was collected from the mice using tubes containing EDTA. Plasma was collected after centrifugation and then stored at $-20^{\circ} \mathrm{C}$ for additional analysis. Leptin levels were measured using an ELISA kit from R \& D Systems (Minneapolis, MN). Insulin levels were determined by using an ELISA kit from Alpco Diagnostics (Windham, NH). Corticosterone was measured using an RIA kit from $\mathrm{R}$ $\&$ D Systems. Glucose concentrations were measured using a glucometer from Lifescan (Milpitas, CA). Growth hormone (GH) and insulin-like growth factor (IGF) levels were determined by using an ELISA and EIA kit from Diagnostic Systems Laboratories (Webster, TX).

Taqman real-time PCR analysis. To measure hypothalamic neuropeptide expression and Stearoyl-CoA desaturase (SCD-1) mRNA levels, we 
A

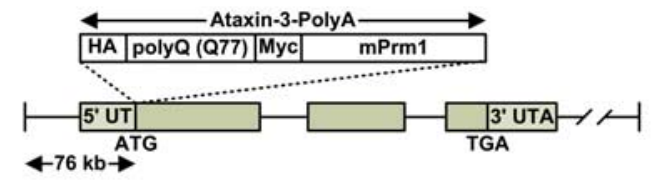

B
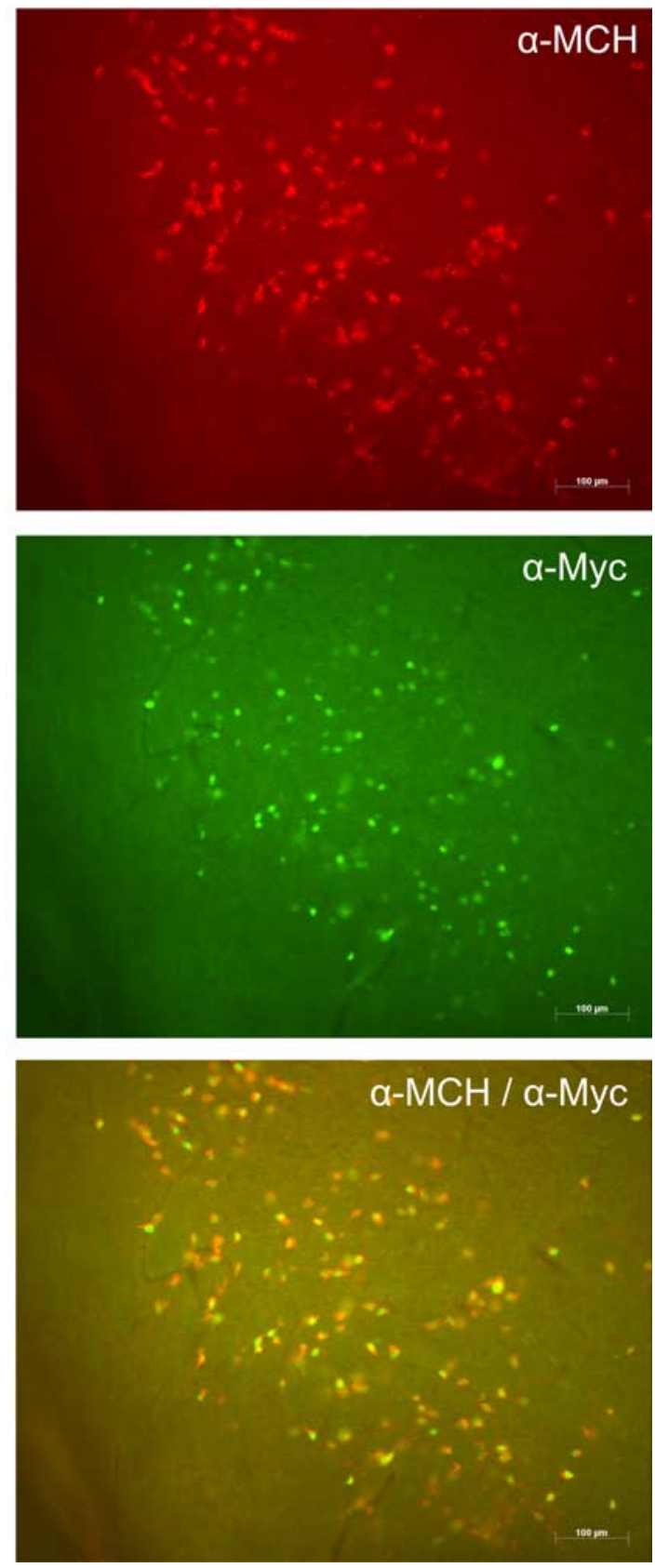

Figure 1. Specific expression of ataxin-3 transgene in $\mathrm{MCH}$-containing neurons in $\mathrm{MCH} /$ ataxin-3 transgenic mice. $\boldsymbol{A}$, Schematic of a modified MCH/ataxin-3 BAC construct. A modified MCH $B A C$ contains $76 \mathrm{~kb}$ of a $5^{\prime} \mathrm{MCH}$ sequence, followed by an ataxin- 3 transgene. The trans gene contains HA epitope, a CDNA fragment starting at amino acid 286 and ending at the $C$ terminus of human mutant ataxin-3, and MYC epitope followed by a murine protamine 1 gene fragment (mPrm1). $\boldsymbol{B}$, Double immunohistochemistry showing colocalization of MYC epitope (green fluorescence) and MCH (red fluorescence) in the lateral hypothalamic area (LH) of a 4-week-old MCH/ataxin-3 transgenic mouse. Bottom, Bright yellow indicates the presence of nuclear aggregates stained by anti-MYC antibody with MCH-containing neurons. Scale bar, $100 \mu \mathrm{m}$. used Taqman real-time PCR analysis. Total RNA was extracted using Trizol (Invitrogen). A reverse transcription kit (Applied Biosystems, Foster city CA) was used for the synthesis of cDNA. Neuropeptide levels were quantified using a Taqman real-time PCR system from Applied Biosystems. All expression data were normalized to cyclophilin expression levels using the same sample. Primers and probes were custom purchased from Applied Biosystems, for measuring agouti-related protein (AGRP), neuropeptide Y (NPY), MCH, proopiomelanocortin (POMC), and SCD-1 mRNA levels.

Statistical analysis. All values are reported as a mean \pm SEM. Statistical tests were performed using an unpaired Student's $t$ test. Statistical analysis of more than three groups was analyzed using ANOVA.

\section{Results}

The ataxin-3 transgene is selectively expressed in neurons containing $\mathrm{MCH}$

$\mathrm{MCH} /$ ataxin-3 BAC transgenic mice were generated by inserting the cytotoxic ataxin-3 transgene in place of the $\mathrm{MCH}$ coding sequence in an MCH BAC transgenic mouse (Yang et al., 1997). The modified MCH BAC contained $76 \mathrm{~kb}$ of $5^{\prime}$ mouse $\mathrm{MCH}$ sequence, followed by/ataxin-3 cassette and $97 \mathrm{~kb}$ of a $3^{\prime}$ mouse $\mathrm{MCH}$ sequence. The ataxin-3 transgene included a cDNA fragment of human ataxin-3 gene with 77 polyglutamine repeats, an $\mathrm{N}$-terminal HA epitope, and a C-terminal MYC epitope followed by a murine protamine 1-gene fragment (mPrm1) (Fig. $1 A)$. The modified BAC DNA construct was microinjected into the pronucleus of fertilized oocytes from $\mathrm{FVB} / \mathrm{n}$ strain to generate five transgenic founder lines. Founder animals were mated with wildtype $\mathrm{FVB} / \mathrm{n}$ mice to generate $\mathrm{F} 1$ transgenic mice.

The expression of an ataxin-3 transgene in $\mathrm{MCH}$ neurons was assessed using double immunohistochemistry. Brain sections from 4-week-old $\mathrm{MCH} /$ ataxin-3 mice were double stained with anti-MYC and anti-MCH antibodies. This analysis showed colocalization of the MYC epitope with the $\mathrm{MCH}$-expressing neurons in the lateral hypothalamus (Fig. $1 B$ ). These neurons contained nuclear aggregates that were positively stained by a MYC antibody. The MYC expression pattern was similar in all transgenic lines, and there was no ectopic expression of MYC immunoreactivity. These results confirmed that the ataxin-3 transgene was specifically expressed in the MCH neurons.

\section{Temporal loss of MCH neurons in the hypothalamus of $\mathrm{MCH} /$ ataxin-3 transgenic mice}

IHC was next performed at different ages to determine whether there was a loss of $\mathrm{MCH}$ neurons in the hypothalamus of $\mathrm{MCH}$ / ataxin-3 transgenic mice. Brain sections from $\mathrm{MCH} /$ ataxin-3 mice were prepared at ages 2, 4, 8, 12, 15, and 24 weeks and immunostained using $\mathrm{MCH}$ and $\mathrm{MYC}$ antibodies revealing a time-dependent loss of $\mathrm{MCH}$ neurons. The expression of ataxin-3 was observed in the brain sections starting with the first postnatal week (data not shown). The ablation of $\mathrm{MCH}$ neurons was first evident during the fourth postnatal week. During the eighth postnatal week, the mice had lost an average of $60 \%$ of their MCH neurons. By week 15, $65 \pm 5 \%$ of the $\mathrm{MCH}$ neurons had disappeared (Fig. 2A). All of the transgenic lines had the same temporal pattern of $\mathrm{MCH}$ loss. We further confirmed the loss of $\mathrm{MCH}$ neurons by measuring the expression of $\mathrm{MCH}$ mRNA in the hypothalamus by Northern blot analysis. There was a marked reduction of $\mathrm{MCH}$ mRNA levels in the hypothalamus of 8 - and 36-week-old MCH/ataxin-3 mice (Fig. 2B). During postnatal week 19, Taqman Real-Time PCR analysis showed that the expression of MCH mRNA decreased by $68 \pm 2.8 \%$ when compared with wild-type littermates (data not shown). These data indicated that the expression of the ataxin-3 transgene re- 
sulted in a time-dependant elimination of a majority of the $\mathrm{MCH}$ neurons in the lateral hypothalamus.

\section{Normal expression of orexin and GFAP in $\mathrm{MCH} /$ ataxin-3 transgenic mice}

There were no gross alterations in the appearance of 24-week-old hematoxylineosin-stained sections of hypothalamus from $\mathrm{MCH} /$ ataxin-3 mice, an age at which there has already been maximal loss of the $\mathrm{MCH}$ neurons (data not shown). To rule out the possibility of nonspecific cell loss in other lateral hypothalamic cell populations, we also examined the level of orexin, a marker for another neuronal cell type in the lateral hypothalamus and GFAP, a glial marker. $\mathrm{MCH}$ and orexin are expressed in distinct neuronal populations in the lateral hypothalamus, and both have been implicated in the regulation of feeding behavior (Guan et al., 2002). We used orexin antibodies to immunostain the brain sections of 8- and 15-week-old MCH/ataxin-3 mice and their wild-type littermates. The number of orexin-containing neurons was unchanged in $\mathrm{MCH} /$ ataxin-3 when compared with wild-type littermates (Fig. 2C). We also used Northern blot analysis to measure the orexin mRNA level in the hypothalamus of 8- and 36-week-old $\mathrm{MCH} /$ ataxin-3 mice. We found no change in the expression level of orexin mRNA in the same samples in which MCH mRNA levels were significantly reduced (Fig. $2 \mathrm{~B}$ ). IHC was also performed using antibodies to GFAP on brain sections of 15 -week-old $\mathrm{MCH} /$ ataxin-3 mice, confirming that there was no evidence of gliosis in the hypothalamus of $\mathrm{MCH} /$ ataxin-3 mice (data not shown). These data suggest that the effect of the $\mathrm{MCH} /$ ataxin-3 transgene was limited to the loss of $\mathrm{MCH}$ neurons.

\section{Ablation of the $\mathrm{MCH}$ neurons in mice leads to a reduction in body weight, fat mass, and body length}

$\mathrm{MCH} /$ ataxin-3 mice were born in mendelian ratios. The mice were viable, fertile, and appeared grossly normal after physical inspection. The weight of these animals was no different than that of the controls until 7 weeks of age. At 7 weeks of age, $\mathrm{MCH} /$ ataxin-3 mice diverged from control animals and showed a significant reduction in body weight when compared with their wild-type littermates $(20.48 \pm 0.5$ vs $22.56 \pm 0.5 \mathrm{~g}, p<$ 0.05 for males; $17.18 \pm 0.56$ vs $20.375 \pm$ $0.6 \mathrm{~g}, p<0.05$ for females). By 22 weeks of age, weight was reduced by $14 \%$ in males and $13 \%$ in females (Fig. $3 A, B)$. Body composition analysis revealed that $\mathrm{MCH}$-ataxin-3 mice had $60 \%$ less fat mass than their wild-type littermates. The fat mass in 18-week-old MCH/ataxin-3 females was $1.2 \pm 0.2 \mathrm{~g}$ (with

B

Orexin

$18 S$
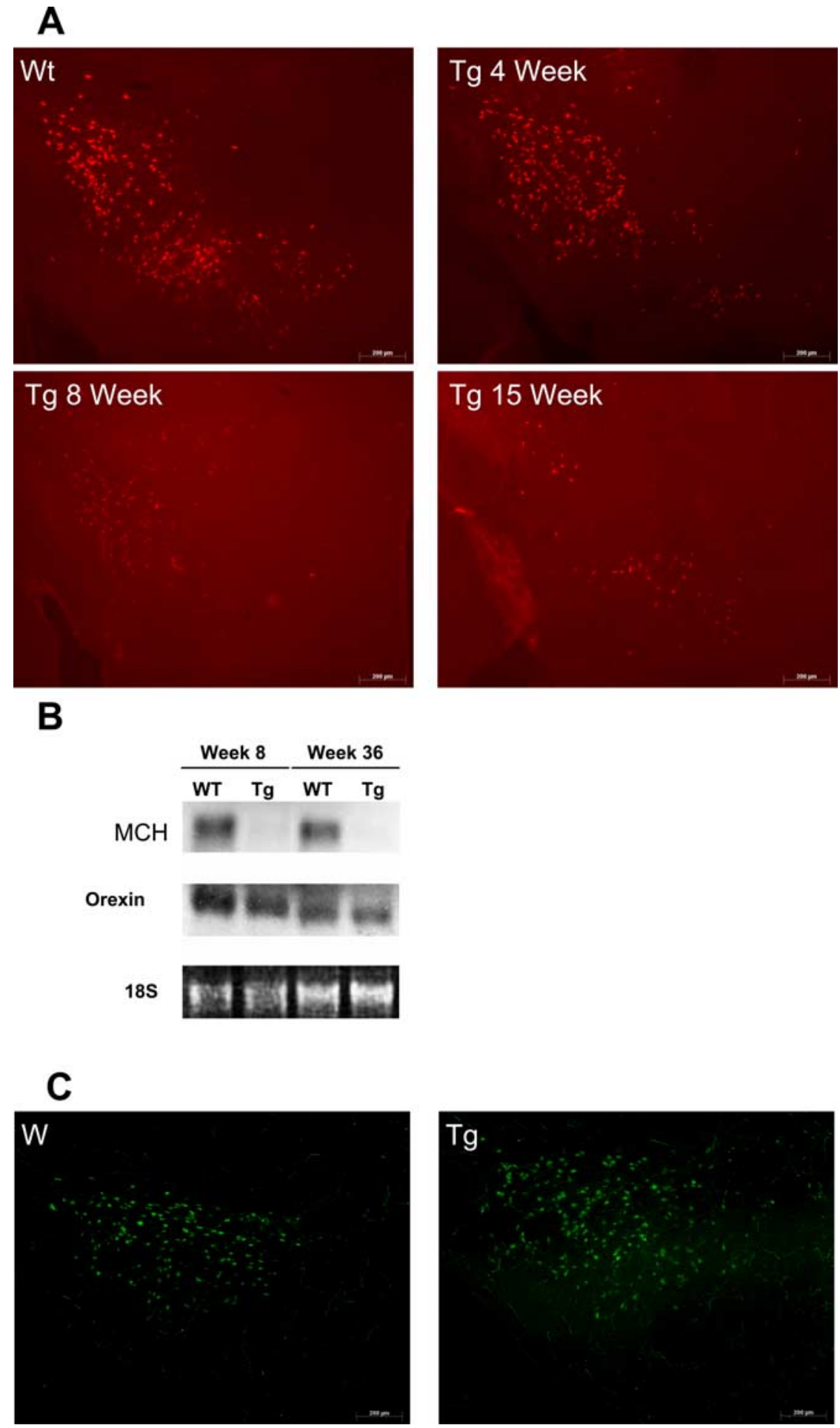

Figure 2. Temporal loss of $\mathrm{MCH}$ neurons accompanies the normal expression of orexin in the hypothalamus of MCH/ataxin-3 transgenic mice. $\boldsymbol{A}$, Immunostaining of matched brain sections from 4-, 8-, and 15-week-old MCH/ataxin-3 transgenic mice (right) and their 4-week-old wild-type littermate (left) using anti-MCH antiserum. Scale bar, $200 \mu \mathrm{m}$. B, Northern blot analysis comparing the expression levels of $\mathrm{MCH}$ and orexin mRNAs in the hypothalamus of 8- and 36-week-old MCH/ataxin-3 mice and their wild-type littermates. An 185 ribosomal mRNA was used to confirm equal loading. C, Anti-orexin immunostaining of matched brain sections of the lateral hypothalamic area from 8-week-old MCH/ataxin-3 mice (right) and their wild-type littermates (left). Scale bar, $200 \mu \mathrm{m}$. Tg, Transgenic; Wt, WT, or W, wild-type.

$5.6 \%$ total body mass), compared with $3 \pm 0.2 \mathrm{~g}$ (with $11.9 \%$ total body mass) in wild-type littermates (Fig. 3C). MCH/ataxin-3 mice also exhibited a small but significant reduction of body length, which was first apparent at 14 weeks of age. At 20 weeks of age, body length 

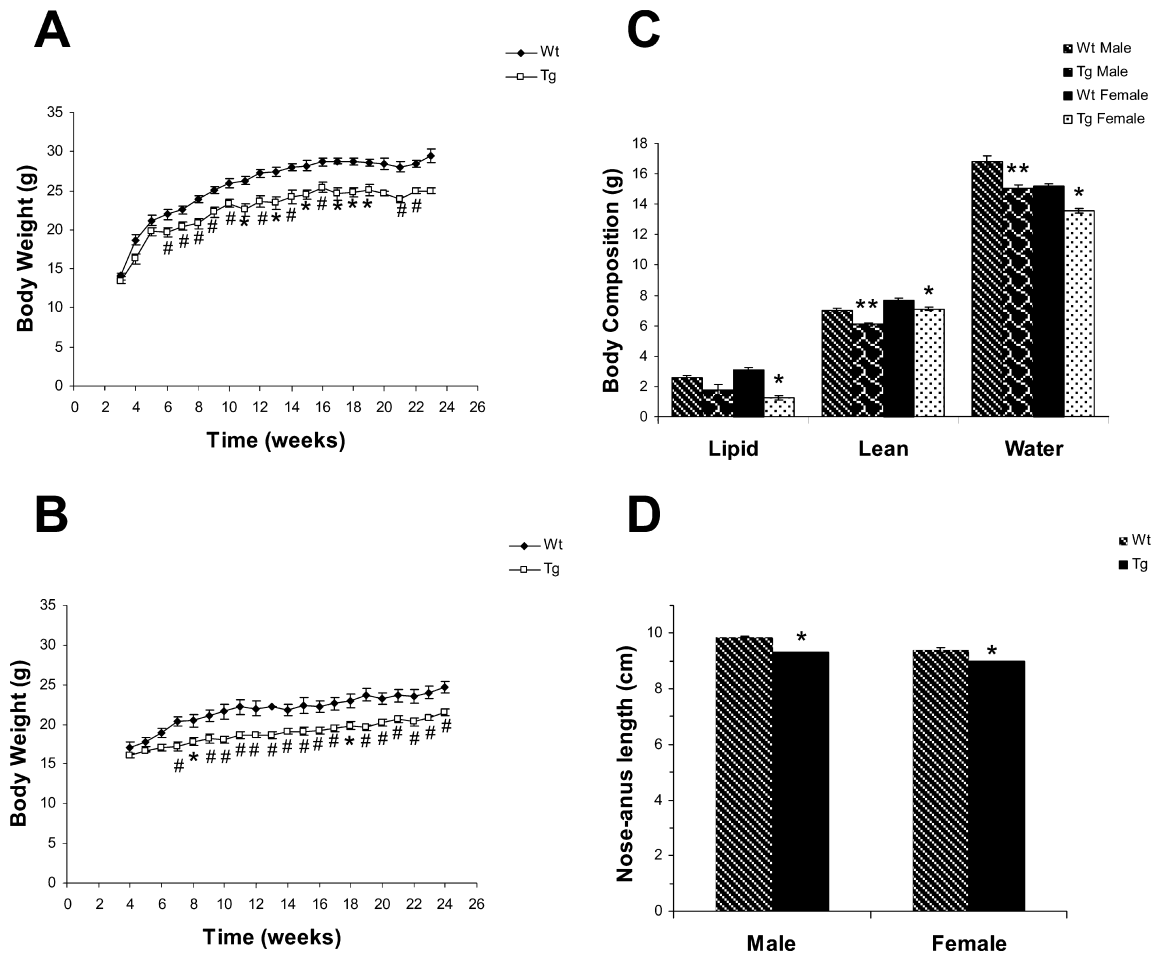

D

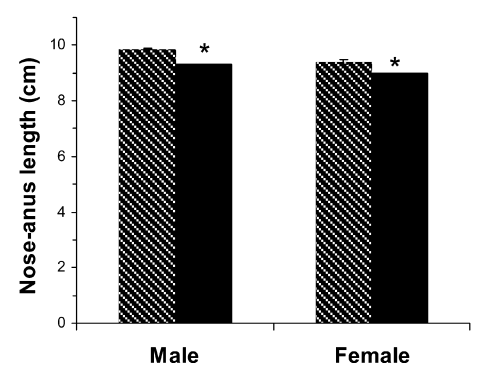

Figure 3. Growth, body composition, and body length in MCH-ataxin-3 mice maintained on a regular diet. $A$, Weight curves of male MCH/ataxin- 3 mice (open squares) and their wild-type littermates (filled diamonds) mice over the course of 23 weeks. $n=$ 6 for each group. ${ }^{*} p<0.005,{ }^{\#} p<0.05$. B. Weight curves of female MCH/ataxin-3 mice (open squares) and their wild-type littermates (filled diamonds) mice over the course of 24 weeks. $n=6$ for each group. ${ }^{*} p<0.005,{ }^{*} p<0.05$. C, Body composition analysis of both 13-week-old male and 18-week-old female MCH/ataxin-3 (shingle-filled bars and dot-filled bars) and their wild-type littermates (downward diagonal filled bars and solid bars) mice showing fat mass, lean mass, and total water. $n=6$ per group, ${ }^{*} p<0.05$ versus wild-type control, ${ }^{* *} p<0.005$. D, Nose-anus length of male and female MCH/ataxin- 3 mice (filled bars) and their wild-type littermates (downward diagonal filled bars) at 20 weeks of age ( $n=6$ in each group). ${ }^{*} p<0.002$. Tg, Transgenic; Wt, wild-type.

was reduced by $4.5 \%$ in females $(9.4 \pm 0.08$ vs $9 \pm 0.01 \mathrm{~cm} ; p<$ $0.002)$ and $6 \%$ in males $(9.86 \pm 0.03$ vs $9.3 \pm 0.01 \mathrm{~cm} ; p<0.002)$ (Fig. 3D). Consistent with this, there was a significant decrease in the percentage of lean mass. $\mathrm{MCH} /$ ataxin-3 mice had $7 \%$ less lean mass than their wild-type littermates. The lean body mass for 18-week-old $\mathrm{MCH} /$ ataxin-3 females was $7.1 \pm 0.1 \mathrm{~g}$ (with $32 \%$ of total weight), whereas it was $7.7 \pm 0.1 \mathrm{~g}$ (with $30 \%$ of total weight) for their wildtype littermates (Fig. 3C). The lean body mass for 13-week-old $\mathrm{MCH} /$ ataxin-3 males was $6.1 \pm 0.1 \mathrm{~g}$ (with $27 \%$ of total weight), whereas it was $7.0 \pm 0.14 \mathrm{~g}$ (with $27 \%$ of total weight) for their wild-type littermates (Fig. 3C).

\section{Mice lacking the MCH neurons exhibited a negative energy balance}

Food intake, locomotor activity, and metabolic rate were measured over $24 \mathrm{~h}$ periods. Total and resting oxygen consumption and carbon dioxide production were measured using the Oxymax system. The food intake of $\mathrm{MCH} /$ ataxin- 3 mice was no different than that of the controls at 8 weeks of age (Fig. 4 A). At 16 weeks of age, female $\mathrm{MCH} /$ ataxin-3 mice consumed 13\% less food than their wild-type littermates over a $24 \mathrm{~h}$ period $(4 \pm 0.2$ vs $4.6 \pm 0.2 \mathrm{~g} / \mathrm{d} ; p<0.03$ ) (Fig. $4 A$ ). Male mice consumed $6.7 \%$ less food than wild-type littermates $(4.5 \pm 0.05$ vs $4.8 \pm 0.1 \mathrm{~g} / \mathrm{d}$; $p<0.05$ ) (Fig. 4A). We did not see a decrease in food intake when our measurements were corrected for body weight. Female $\mathrm{MCH} /$ ataxin-3 mice consumed as much as their wild-type littermates over a $24 \mathrm{~h}$ period $(0.200886 \pm 0.010796$ vs $0.204048 \pm$
$0.007986 \mathrm{~g} / \mathrm{kg} / \mathrm{d} ; p>0.05)$. Male mice also consumed as much as their wild-type littermates $(0.19 \pm 0.006$ vs $0.192 \pm 00.12$ $\mathrm{g} / \mathrm{kg} / \mathrm{d} ; p>0.05)$. The mice had a normal diurnal feeding pattern consuming most of their calories during the dark cycle. The reduction in food intake was observed during both dark and light cycles (data not shown).

The effects of the ablation of $\mathrm{MCH}$ neurons on energy expenditure were sexually dimorphic with significant effects evident in males but not females. Male MCH/ataxin-3 mice showed an increase of $27.6 \%$ in total and $26.1 \%$ in resting $\mathrm{VO} 2$ (Fig. $4 B$ ) [total $4473.6 \pm 300.6 \mathrm{ml} / \mathrm{kg} / \mathrm{hr}$ in $\mathrm{MCH} /$ ataxin-3 mice vs $3507.1 \pm 119.6 \mathrm{ml} / \mathrm{kg} / \mathrm{hr}$ in littermates $(p<0.009)$; resting VO2, $4009.2 \pm$ $171.8 \mathrm{ml} / \mathrm{kg} / \mathrm{hr}$ in $\mathrm{MCH} /$ ataxin-3 mice vs $3178.6 \pm 146.7 \mathrm{ml} / \mathrm{kg} / \mathrm{hr}$ in littermates $(p<$ 0.004)]. Carbon dioxide production (VCO2) was increased by $20.3 \%$ in the male mice $(4238.8 \pm 251.8 \mathrm{ml} / \mathrm{kg} / \mathrm{hr}$ in $\mathrm{MCH}$ mice and $3524.2 \pm 542.8 \mathrm{ml} / \mathrm{kg} / \mathrm{hr}$ in their wild-type littermates; $p<0.05$ ). Locomotor activity was equivalent in both males and females. Together, these data indicate that hypophagia contributes to the leanness of $\mathrm{MCH} /$ ataxin-3 with an added effect in males secondary to an increase in energy expenditure.

\section{Neuroendocrine function}

Plasma leptin levels were reduced by $30 \%$ in 19-week-old females compared with their wild-type littermates $(1.9 \pm 0.07$ vs $2.7 \pm 0.34 \mathrm{ng} / \mathrm{ml} ; p<0.05 ; n=6)$. However, this difference was no longer evident in 28-week-old females (data not shown). Levels of glucose were not significantly different between 19-weekold females and their wild-type littermates, whereas 28 -week-old males had 20\% reduction in glucose levels. Female 19-weekold mice had a $20 \%\left(0.39 \pm 0.01 \mathrm{ng} \mathrm{ml}^{-1}\right)$ reduction in insulin levels when compared with their wild-type littermates $(0.49 \pm$ $0.01 \mathrm{ng} \mathrm{ml}^{-1} ; p<0.05 ; n=6$ ). Corticosterone levels were unchanged in 19-week-old mice (data not shown). Our analysis shows that $\mathrm{MCH} /$ ataxin-3 mice are hypoleptinemic, which is consistent with their lean phenotype. The reduced insulin levels also suggest that the loss of MCH neurons may lead to a slight increase in the insulin sensitivity of the mice.

Plasma levels of GH and insulin-like growth factors (IGF-I) were not significantly different between $\mathrm{MCH} /$ ataxin-3 mice and their wild-type littermates. We found that IGF-I levels in 13week-old females and males were $1083 \pm 107$ and $1331.2 \pm 274.8$ $\mathrm{ng} / \mathrm{ml}$, whereas the levels for their wild-type littermates were $1007 \pm 115$ and $1156.19 \pm 166 \mathrm{ng} / \mathrm{ml}$. We also found that $\mathrm{GH}$ levels in 13-week-old females and males were $12.2 \pm 1.6$ and $14.1 \pm 3 \mathrm{ng} / \mathrm{ml}$, whereas their wild-type littermates were $9.6 \pm$ 0.45 and $10.9 \pm 1.4 \mathrm{ng} / \mathrm{ml}$.

Hypoleptinemia generally leads to an increase in NPY and AGRP RNA levels and a reduction of POMC RNA levels in the hypothalamus (Hillebrand et al., 2002). However, this was not the case in the $\mathrm{MCH} /$ ataxin-3 knock-out mice in which there were no significant changes in the expression of the RNAs for 


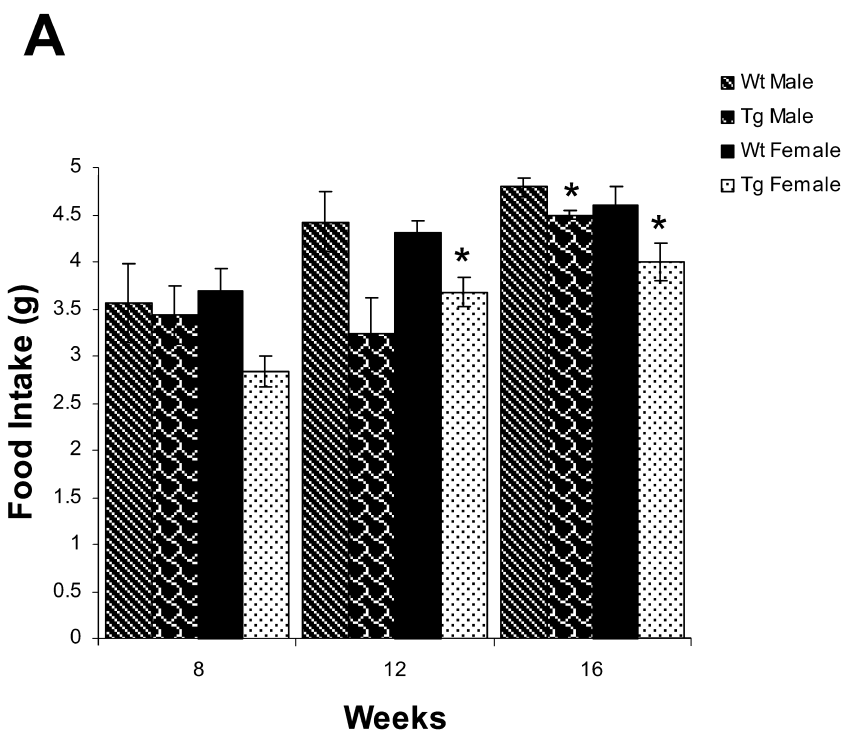

B

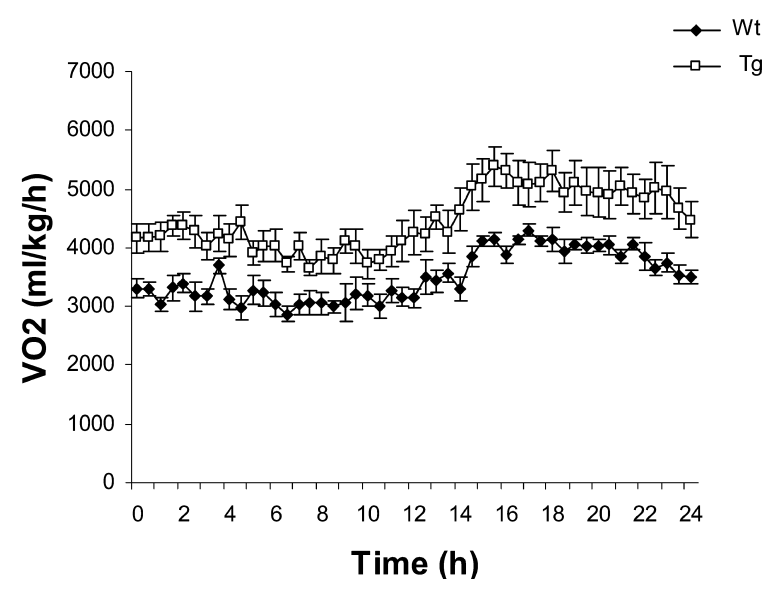

Figure 4. Food intake and metabolic rate in $\mathrm{MCH}$ /ataxin-3 transgenic mice. $A$, Average daily food intake of both male and female MCH/ataxin-3 (shingle-filled bars and dot-filled bars) and their wild-type littermates (downward diagonal filled bars and solid bars) mice at 8, 12, and 16 weeks of age. ${ }^{*} p<0.03(n=7)$. $\boldsymbol{B}, 0 x y$ gen consumption (in 30 min intervals) of 17-week-old male MCH/ataxin-3 mice (open squares) and their wild-type littermates (filled diamonds) during a $24 \mathrm{~h}$ period as measured by an 0xymax monitoring system ( $n=6$ in each group). $\mathrm{Tg}$, Transgenic; WT, wild-type.

these neuropeptides, in 19-week-old female MCH/ataxin-3 mice (Fig. 5).

\section{$\mathrm{MCH} /$ ataxin-3 mice exhibited a normal response to fasting,} leptin treatment, and deficiency

We next assessed the response of $\mathrm{MCH} /$ ataxin-3 mice to fasting and acute and chronic leptin deficiency, first in studies of food intake and body weight in mice before and after fasting for $24 \mathrm{~h}$. Weight loss after a fast was similar in both groups. When provided with food after $24 \mathrm{~h}$ of fasting, younger 19-week-old MCH/ ataxin-3 mice initially consumed less food than controls during the first 3 and $6 \mathrm{~h}(2.1 \pm 0.1$ vs $2.83 \pm 0.2 \mathrm{~g} ; p<0.007)$. However, by $24 \mathrm{~h}$, the animals had caught up and food intake was unchanged between the groups after $24 \mathrm{~h}(6.4 \pm 0.08$ vs $6.6 \pm 0.19 \mathrm{~g})$ (Fig. 6A). This reduction of food intake at early times after fasting

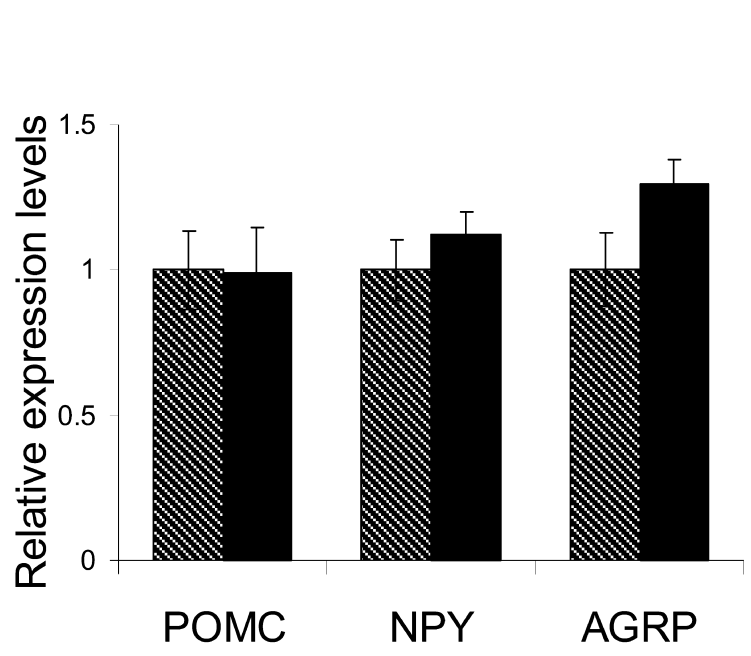

Figure 5. Hypothalamic neuropeptide mRNAs in $\mathrm{MCH} /$ ataxin-3 mice. Expression levels of POMC, NPY, and AGRP in the hypothalamus of 19-week-old female MCH/ataxin-3 mice (filled bars; $n=6$ ) mice and their wild-type (Wt) littermates (downward diagonal filled bars; $n=6$ ) using a real-time quantitative reverse transcription-PCR. Tg, Transgenic.

was no longer evident in older 24-week-old animals. In both groups, weight gain following a fast was also equivalent. These data demonstrate that although there is an initially sluggish response to fasting, $\mathrm{MCH} /$ ataxin-3 mice exhibited a normal compensatory hyperphagic response to fasting.

Leptin has been suggested to modulate the activity of the $\mathrm{MCH}$ system (Huang et al., 1999). To investigate the response of $\mathrm{MCH} /$ ataxin-3 mice to leptin, the effect of $9 \mathrm{~d}$ of leptin treatment on food intake and body weight in 19-week-old MCH/ataxin-3 male was determined. $\mathrm{MCH} /$ ataxin-3 mice responded with equivalent reductions in food intake and body weight as controls (45\% reduction of food intake at day 2 and a $13 \%$ decrease of body weight at day 9) (Fig. $6 \mathrm{~B}, \mathrm{C}$ ). In addition, using a protocol that leads to acute leptin deficiency, the hyperphagic response to leptin withdrawal was also normal in the MCH/ataxin-3 animals. In these experiments, we treated the mice with high dose subcutaneous leptin followed by abrupt leptin withdrawal (Montez et al., 2004). This protocol leads to a state of acute leptin deficiency that is followed by a robust and predictable period of hyperphagia. Four days after leptin withdrawal, MCH/ataxin-3 mice showed a $35.8 \pm 4.5 \%$ increase in food intake, whereas wild-type mice consumed $33.4 \pm 5.2 \%$ more food when compared with the baseline (Fig. 6B). The baseline was the average food consumption for $24 \mathrm{~h}$ measured over a 3 day period before leptin treatment. Weight gain was also equivalent in both groups when compared with the baseline (Fig. $6 C$ ). The baseline was the body weight measured for $2 \mathrm{~d}$ before the leptin treatment.

\section{The loss of MCH neurons lead to the attenuation of the} ob/ob phenotype

We next assessed whether, similar to the effects of an MCH mutation, the ablation of $\mathrm{MCH}$ neurons could also attenuate an obese phenotype. Despite the fact that the biologic response to starvation, leptin treatment, and acute leptin deficiency was unchanged, the ablation of $\mathrm{MCH}$ neurons did lead to a significant alteration in the response to congenital leptin deficiency in ob/ob mice. $\mathrm{C} 57 \mathrm{BL} / 6 \mathrm{~J} \mathrm{ob} /+$ and $\mathrm{MCH} /$ ataxin-3 mice were intercrossed to generate $\mathrm{MCH} /$ ataxin-3/ob/ob mice. The $\mathrm{MCH} /$ ataxin-3/ $\mathrm{ob} / \mathrm{ob}$ mice showed a significant reduction in body weight when compared with ob/ob mice. At 24-28 weeks of age, weight was 
A

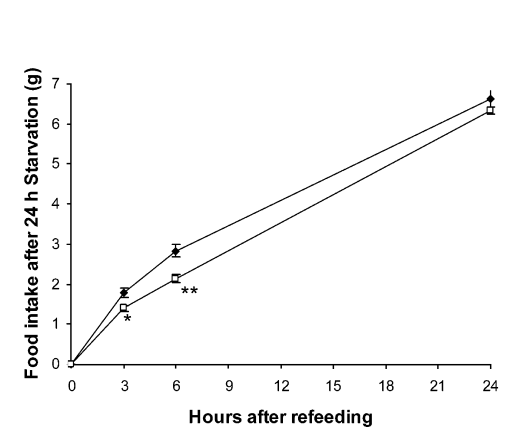

B

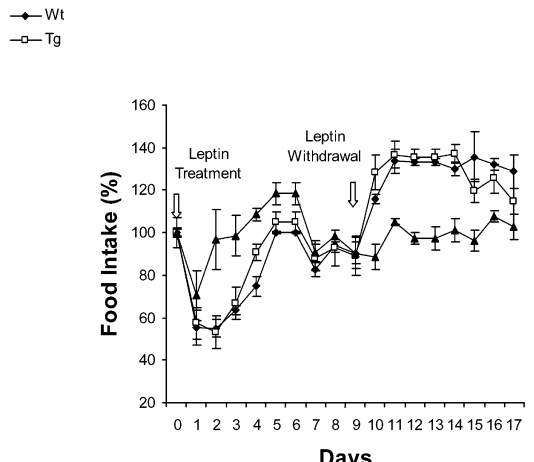

Days

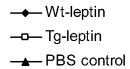

$\leftarrow$ PBS control

- Tg-leptin

$\Delta$ PBS control

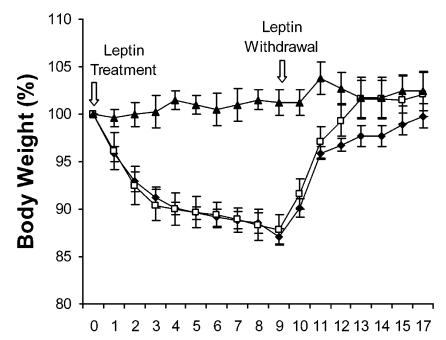

Days

Figure 6. $M C H / a t a x i n-3$ mice exhibited a normal response to fasting, leptin treatment, and leptin deficiency. A, Cumulative food intake in response to $24 \mathrm{~h}$ starvation in 19 -week-old male MCH/ataxin-3 mice (open squares; $n=5$ ) and their wild-type littermates (wt; filled diamonds; $n=6$ ). ${ }^{*} p<0.03,{ }^{* *} p<0.007 . \boldsymbol{B}, \boldsymbol{C}$, Food intake $(\boldsymbol{B})$ and body weight ( $(\boldsymbol{)})$ in response to $9 \mathrm{~d}$ of leptin treatment followed by $8 \mathrm{~d}$ of leptin withdrawal in 19-week-old male MCH/ataxin-3 mice (open squares; $n=6$ ) and their wild-type littermates (filled diamonds; $n=6$ ) compared with PBS control mice (filled triangles; $n=4$ ). Food intake and body weight are represented as a percentage of the baseline. The food intake baseline was an average of the food consumption for $24 \mathrm{~h}$ measured over a $3 \mathrm{~d}$ period before leptin treatment. The body weight baseline was body weight measured $2 \mathrm{~d}$ before leptin treatment. Tg, Transgenic.
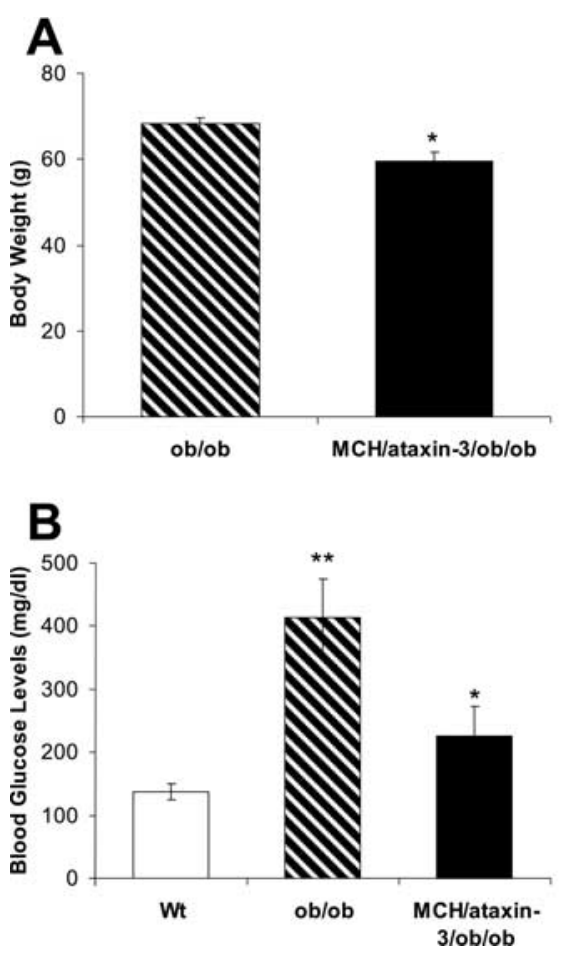

Figure 7. The loss of MCH neurons in ob/ob mice improved obesity, diabetes, and hepatic abnormalities. $A$, Body weight in 24to 28-week-old female MCH/ataxin-3/ob/ob (filled bar; $n=7$ ) and ob/ob control (downward diagonal filled bar; $n=10$ ) mice. ${ }^{*} p<0.004$. B, Glucose levels in 24- to 28-week-old female MCH/ataxin-3/ob/ob (filled bar; $n=10$ ), ob/ob control mice (downward diagonal filled bar; $n=8$ ), and wild-type mice (wt; dot-filled bar; $n=6$ ). ${ }^{*} p<0.03$, ${ }^{* *} p<0.002$. C, Photographs of freshly dissected livers from 24-week-old female MCH/ataxin-3/ob/ob (center), ob/ob control (left), and wild-type (right) mice. D, Hematoxylin and eosin staining of liver sections from female MCH/ataxin-3/ob/ob (right) and ob/ob control (left) (females, $n=3$; males, $n=2)$. Scale bar, $20 \mu \mathrm{m}$.

reduced by $13 \%$ in females $(60 \pm 2.1$ vs $68 \pm 1.3 \mathrm{~g} ; p<0.004)$ (Fig. 7A). Mice lacking both leptin and MCH neurons also exhibited a significant reduction in plasma glucose concentration $(226 \pm 46$ vs $414 \pm 61 \mathrm{mg} / \mathrm{dl} ; p<0.02)$ (Fig. $7 B)$ and no change in insulin levels. There was also a marked improvement in hepatomegaly and steatosis in the ob/ob mice lacking $\mathrm{MCH}$ neurons (average liver weight, $2.6 \mathrm{~g}$ for $\mathrm{MCH} /$ ataxin-3 ob/ob mice vs $4.4 \mathrm{~g}$ in ob/ob animals vs $1 \mathrm{~g}$ for wild-type mice (Fig. $7 C$ ). In histologic sections, the steatosis characteristic of ob/ob mice was normalized by ablation of
MCH neurons (Fig. 7D). In addition, the hepatic SCD-1 gene expression was decreased by $34 \%$ in $\mathrm{MCH} /$ ataxin-3/ob/ob mice when compared with ob/ob (data not shown). There was also an improvement in fertility for both $\mathrm{MCH} /$ ataxin-3/ob/ob and ob/ob control mice. All mice had a mixed C57BL/6J and FVB/N genetic background. Fertile male mice were comprised of $12.5 \%$ of the ob/ob and $12.5 \%$ of the $\mathrm{MCH} / \mathrm{ob} / \mathrm{ob}$, whereas female fertile mice were comprised of $33 \%$ of the ob/ob and $30 \%$ of the $\mathrm{MCH} /$ $\mathrm{ob} / \mathrm{ob}$. The fertile females produced normal size litters but were unable to nurture their pups through weaning. These data indicate that the ablation of $\mathrm{MCH}$ neurons can also reduce an already developed obese phenotype in adult animals.

\section{Discussion}

In this study, we generated mice with selective loss of $\mathrm{MCH}$ neurons using a toxin (ataxin-3)-mediated ablation strategy. We showed that the selective loss of the $\mathrm{MCH}$ neurons leads to an acquired, late onset reduction of body weight. These results suggest the possibility that late onset changes in body weight could in some cases be the result of the loss of specific neural populations in the hypothalamus.

Obesity is a complex multifactorial condition influenced by genetic and environmental factors. Genetic factors account for a substantial fraction of the variance in body weight. However, in some instances, substantial changes in body weight, in either direction, develop later in life. Although it is possible that these alterations have a genetic component, these changes could also be caused by environmental factors acting on susceptible genetic factors. One theoretical possibility for changes in weight later in life is that key neurons that regulate food intake and body weight are lost. In humans, it is known that hypothalamic lesions resulting from tumors, sarcoid, or viral infections 
(in the case of animals), such as canine distemper virus, can cause dramatic changes in weight (Bray and Gallagher, 1975; Lyons et al., 1982; Carmel, 1985). However, these lesions are generally associated with easily discernable histologic changes. It is also possible that acquired changes in weight could result from the selective loss of specific classes of neurons without their being any evident gross histologic changes. This theoretical possibility is illustrated by the recent realization that sporadic cases of narcolepsy are the result of the spontaneous loss of orexin neurons in the lateral hypothalamus later in life (Hara et al., 2001). Although the pathogenesis of the neural loss for this condition is unknown, it has been suggested that it could be attributed to undefined environmental factors that act on a susceptible genetic background. One of the predisposing factors is associated with HLA, suggesting that an autoimmune component might be the cause of the selective destruction of orexin neurons (Carlander et al., 2001; Smith et al., 2004). These seminal findings in narcolepsy research suggest that the loss of different neuronal populations in hypothalamus could lead to physiologic alterations in other biologic functions controlled by this brain region. Additional studies will be necessary to determine the contributions of environmental factors and their interaction with genetic risk factors in the pathogenesis of weight changes later in life.

In this study, we ablated MCH neurons to test the possibility that specific neural loss could lead to late onset alterations in the homeostatic control of energy balance. $\mathrm{MCH}$-expressing neurons are localized exclusively in the lateral hypothalamus in which they are found in a nonoverlapping distribution with orexin (Guan et al., 2002). MCH is a potent orexigenic mediator and a key central regulator of energy homeostasis ( $\mathrm{Qu}$ et al., 1996). Mutations in the MCH gene reduce food intake and body weight, making the expressing neurons attractive candidates for testing the possibility that the loss of this population might be associated with the development of an extremely lean phenotype later in life without changing viability. Here, we show that mice lacking $\mathrm{MCH}$ neurons are viable but develop a late onset nutritional disorder characterized by extreme leanness.

Although traditional methods, such as diphteria toxin gene product and herpes simplex virus 1 thymidine kinase, have been used in the past for cell ablation, they are not very effective when ablating neural postmitotic cells. Therefore, $\mathrm{MCH}$ neurons were ablated using a toxin-mediated cell ablation strategy using the human ataxin-3 gene. This mutant protein has an expanded number of polyglutamine repeats, which leads to the toxic cell death of neurons that express it (Paulson et al., 1997; Bevivino and Loll, 2001). The ataxin-3 transgene has been used before for the ablation of orexin neurons in vivo (Hara et al., 2001). We generated $\mathrm{MCH} /$ ataxin-3 transgenic mice by introducing an ataxin-3 cassette into the initiation codon of the $\mathrm{MCH}$ gene via homologous recombination in a bacterial strain carrying an $\mathrm{MCH}$ bacterial artificial chromosome (Yang et al., 1997). MCH cell-specific expression of the ataxin-3 transgene specifically in $\mathrm{MCH}$ neurons was confirmed in multiple different transgenic lines suggesting that the $76 \mathrm{~kb}$ of $5^{\prime}$ and $97 \mathrm{~kb}$ of $3^{\prime}$ sequences in this BAC are sufficient to confer correct expression of the MCH gene. This BAC can now be used to direct the expression of other proteins or reporters to these neurons with a high likelihood of correct expression.

The phenotype of the MCH/ataxin-3 mice was remarkably similar to that of mice with induced mutations of the $\mathrm{MCH}$ gene (Shimada et al., 1998). In both cases, the mice exhibited reduced body weight, fat mass, and leptin levels with reduced food intake and an increase of energy expenditure. It has also been shown that the ablation of MCH1-R (the receptor for $\mathrm{MCH}$ ) lead to an increase in locomotor activity (Chen et al., 2002). If anything, it is likely that the $\mathrm{MCH} /$ ataxin-3 mice have slightly less severe phenotypes, because the neuronal ablation was not complete. Although the $\mathrm{MCH}$ neurons are likely to express classical neurotransmitters and potentially other neuropeptides, the similarity of the phenotypes suggest that $\mathrm{MCH}$ itself is a major mediator of the physiologic actions of these neurons. The only notable difference between the MCH knock-out mice and the MCH/ataxin-3 mice was in the linear growth in which the ablation of $\mathrm{MCH}$ neurons resulted in a mild decrease in skeletal growth and lean mass. It is possible that this is the result of actions of other neuromodulators in these neurons on the somatotropic axis, including GH, IGF-I, IGF binding proteins, and IGF receptors, which is regulated by nutritional state and endocrine mechanisms (Bornfeldt et al., 1989; Renaville et al., 2002). However, our data showed that the levels of GH and IGF-I were not significantly different between $\mathrm{MCH} /$ ataxin-3 mice and their wild-type littermates. Additional studies are needed to elucidate the mechanisms leading to the decreased skeletal growth.

Numerous previous studies have confirmed that leptin acts as a positive regulator of POMC and CART while acting as a negative regulator of AGRP and NPY (Elias et al., 1998; Hillebrand et al., 2002). Consistent with this, POMC gene expression is reduced in the hypothalamus of MCH knock-out mice. In contrast, the levels of POMC and AGRP RNA were not altered in the hypothalami of the $\mathrm{MCH} /$ ataxin-3 mice despite the fact that the leptin levels were reduced (Shimada et al., 1998). This result could mean that $\mathrm{MCH}$ neurons normally modulate POMC gene expression in an $\mathrm{MCH}$-independent manner. Bidirectional communication has been demonstrated between $\mathrm{MCH}$-expressing neurons in the lateral hypothalamus and the arcuate-expressing neurons, such as POMC, NPY, and AGRP (Elias et al., 1998).

Both the MCH knock-out and ablation of $\mathrm{MCH}$ neurons significantly reduce the obesity associated with leptin mutations (Segal-Lieberman et al., 2003). Thus, MCH neurons play an important role in mediating the orexigenic response to chronic leptin deficiency. In contrast, the ablation of these neurons does not appreciably alter the biologic response to fasting or acute leptin deficiency (induced using a leptin withdrawal protocol), both of which are normal in the $\mathrm{MCH} /$ ataxin-3 mice. The basis for this difference is not clear. It may be that acute changes in food intake or body weight activate multiple, potentially independent pathways, whereas chronic leptin deficiency activates fewer such pathways. It is noteworthy, however, that neither the ablation of $\mathrm{MCH}$ neurons nor $\mathrm{MCH}$ mutations completely normalize the weight of ob mice, suggesting that other pathways also play a role in the response to chronic leptin deficiency (Erickson et al., 1996).

The toxin-mediated ablation approach has also been used in the ablation of orexin neurons (Hara et al., 2001). Both MCH and orexin are expressed in separate neuronal populations within the lateral hypothalamus area and have been implicated in feeding regulation (Hara et al., 2001; Guan et al., 2002). Orexin neurons have been linked to arousal and sleep regulation. The roles of $\mathrm{MCH}$ in feeding regulation are different from those of orexin. Mice lacking orexin neurons exhibited a late-onset obesity despite their reduced food intake. Their obesity was characterized by reduced energy expenditure because of a decrease in motor activity and metabolic rate. Although mice lacking $\mathrm{MCH}$ neurons, exhibited a late onset leanness because of hypophagia and an increased metabolic rate. These differences suggest that $\mathrm{MCH}$ and orexin may play different roles in energy metabolism regulation.

In summary, $\mathrm{MCH} /$ ataxin-3 mice develop a late onset syndrome characterized by leanness, hypophagia, and, in males, increased energy expenditure without any obvious changes in the 
gross histologic appearance of the hypothalamus. Indeed, the basis for the phenotype in these animals would not be evident without the use of specific antisera for $\mathrm{MCH}$ immunostaining. These results thus raise the possibility that selective loss of specific classes of neurons, undetectable using standard methods, can lead to a late onset change of body weight. Although it would be overly speculative to suggest that weight loss associated with anorexia nervosa, cancer cachexia, or other nutritional disorders could be associated with the loss of the MCH cell population, this possibility can be easily tested. The loss of other neuronal populations might also be expected to lead to alterations of weight, raising the possibility that selective loss of arcuate NPY/AGRP neurons might also lead to weight loss, whereas the specific loss arcuate POMC neurons might result in obesity. Overall, these results suggest that the use of immunohistochemistry to assess the numbers of key hypothalamic neurons might prove relevant in understanding the basis for significant changes in weight or possibly other homeostatic systems later in life.

\section{References}

Bevivino AE, Loll PJ (2001) An expanded glutamine repeat destabilizes native ataxin-3 structure and mediates formation of parallel beta-fibrils. Proc Natl Acad Sci USA 98:11955-11960.

Bittencourt JC, Presse F, Arias C, Peto C, Vaughan J, Nahon JL, Vale W, Sawchenko PE (1992) The melanin-concentrating hormone system of the rat brain: an immuno- and hybridization histochemical characterization. J Comp Neurol 319:218-245.

Bornfeldt KE, Arnqvist HJ, Enberg B, Mathews LS, Norstedt G (1989) Regulation of insulin-like growth factor-I and growth hormone receptor gene expression by diabetes and nutritional state in rat tissues. J Endocrinol 122:651-656.

Borsu L, Presse F, Nahon JL (2000) The AROM gene, spliced mRNAs encoding new DNA/RNA-binding proteins are transcribed from the opposite strand of the melanin-concentrating hormone gene in mammals. J Biol Chem 275:40576-40587.

Bray GA, Gallagher Jr TF (1975) Manifestations of hypothalamic obesity in man: a comprehensive investigation of eight patients and a review of the literature. Med 54:301-330.

Carlander B, Dauvilliers Y, Billiard M (2001) Immunological aspects of narcolepsy. Rev Neurol 157:S97-S100.

Carmel PW (1985) Vegetative dysfunctions of the hypothalamus. Acta Neurochir (Wien) 75:113-121.

Chambers J, Ames RS, Bergsma D, Muir A, Fitzgerald LR, Hervieu G, Dytko GM, Foley JJ, Martin J, Liu WS, Park J, Ellis C, Ganguly S, Konchar S, Cluderay J, Leslie R, Wilson S, Sarau HM (1999) Melanin-concentrating hormone is the cognate ligand for the orphan G-protein-coupled receptor SLC-1. Nature 400:261-265.

Chen Y, Hu C, Hsu CK, Zhang Q, Bi C, Asnicar M, Hsiung HM, Fox N, Slieker LJ, Yang DD, Heiman ML, Shi Y (2002) Targeted disruption of the melanin-concentrating hormone receptor-1 results in hyperphagia and resistance to diet-induced obesity. Endocrinology 143:2469-2477.

DiLeone RJ, Georgescu D, Nestler EJ (2003) Lateral hypothalamic neuropeptides in reward and drug addiction. Life Sci 73:759-768.

Elias CF, Saper CB, Maratos-Flier E, Tritos NA, Lee C, Kelly J, Tatro JB, Hoffman GE, Ollmann MM, Barsh GS, Sakurai T, Yanagisawa M, Elmquist JK (1998) Chemically defined projections linking the mediobasal hypothalamus and the lateral hypothalamic area. J Comp Neurol 402:442-459.

Erickson JC, Hollopeter G, Palmiter RD (1996) Attenuation of the obesity syndrome of ob/ob mice by the loss of neuropeptide Y. Science 274:1704-1707.

Gomori A, Ishihara A, Ito M, Mashiko S, Matsushita H, Yumoto M, Ito M, Tanaka T, Tokita S, Moriya M, Iwaasa H, Kanatani A (2003) Chronic intracerebroventricular infusion of MCH causes obesity in mice. Am J Physiol Endocrinol Metab 284:E583-E588.

Guan JL, Uehara K, Lu S, Wang QP, Funahashi H, Sakurai T, Yanagizawa M, Shioda S (2002) Reciprocal synaptic relationships between orexin- and melanin-concentrating hormone-containing neurons in the rat lateral hypothalamus: a novel circuit implicated in feeding regulation. Int J Obes Relat Metab Disord 26:1523-1532.

Halaas JL, Gajiwala KS, Maffei M, Cohen SL, Chait BT, Rabinowitz D, Lallone RL, Burley SK, Friedman JM (1995) Weight-reducing effects of the plasma protein encoded by the obese gene. Science 269:543-546.

Hara J, Beuckmann CT, Nambu T, Willie JT, Chemelli RM, Sinton CM, Sugiyama F, Yagami K, Goto K, Yanagisawa M, Sakurai T (2001) Genetic ablation of orexin neurons in mice results in narcolepsy, hypophagia, and obesity. Neuron 30:345-354.

Hill J, Duckworth M, Murdock P, Rennie G, Sabido-David C, Ames RS, Szekeres P, Wilson S, Bergsma DJ, Gloger IS, Levy DS, Chambers JK, Muir AI (2001) Molecular cloning and functional characterization of MCH2, a novel human MCH receptor. J Biol Chem 276:20125-20129.

Hillebrand JJ, de Wied D, Adan RA (2002) Neuropeptides, food intake and body weight regulation: a hypothalamic focus. Peptides 23:2283-2306.

Huang Q, Viale A, Picard F, Nahon J, Richard D (1999) Effects of leptin on melanin-concentrating hormone expression in the brain of lean and obese Lep(ob)/Lep(ob) mice. Neuroendocrinology 69:145-153.

Kokkotou EG, Tritos NA, Mastaitis JW, Slieker L (2001) Maratos-Flier E Melanin-concentrating hormone receptor is a target of leptin action in the mouse brain. Endocrinology 142:680-686.

Ludwig DS, Tritos NA, Mastaitis JW, Kulkarni R, Kokkotou E, Elmquist J, Lowell B, Flier JS, Maratos-Flier (2001) E Melanin-concentrating hormone over expression in transgenic mice leads to obesity and insulin resistance. J Clin Invest 107:379-386.

Lyons MJ, Faust IM, Hemmes RB, Buskirk DR, Hirsch J, Zabriskie JB (1982) A virally induced obesity syndrome in mice. Science 216:82-85.

Montez JM, Soukas A, Asilamaz E, Fayzikhodjaeva G, Fantuzzi G, Friedman JM (2004) Acute leptin deficiency, leptin resistance and the physiologic response to leptin withdrawal. Proc Natl Acad Sci USA 102:2537-2542.

Paulson HL, Das SS, Crino PB, Perez MK, Patel SC, Gotsdiner D, Fischbeck KH, Pittman RN (1997) Machado-Joseph disease gene product is a cytoplasmic protein widely expressed in brain. Ann Neurol 41:453-462.

Qu D, Ludwig DS, Gammeltoft S, Piper M, Pelleymounter MA, Cullen MJ, Mathes WF, Przypek R, Kanarek R, Maratos-Flier E (1996) A role for melanin-concentrating hormone in the central regulation of feeding behaviour. Nature 380:243-247.

Renaville R, Hammadi M, Portetelle D (2002) Role of the somatotropic axis in the mammalian metabolism. Domest Anim Endocrinol 23:351-360.

Sambrook J, Fritsch EF, Maniatis T (1989) Molecular cloning: a laboratory manual, Ed 2. Cold Spring Harbor, NY: Cold Spring Harbor Laboratory.

Segal-Lieberman G, Bradley RL, Kokkotou E, Carlson M, Trombly DJ, Wang X, Bates S, Myers Jr MG, Flier JS, Maratos-Flier E (2003) Melaninconcentrating hormone is a critical mediator of the leptin-deficient phenotype. Proc Natl Acad Sci USA 100:10085-10090.

Shimada M, Tritos NA, Lowell BB, Flier JS, Maratos-Flier E (1998) Mice lacking melanin-concentrating hormone are hypophagic and lean. Nature 396:670-674.

Smith AJ, Jackson MW, Neufing P, McEvory RD, Gordon TP (2004) Functional autoantibody in narcolepsy. Lancet 364:2122-2124.

Toumaniantz G, Bittencourt JC, Nahon JL (1996) The rat melaninconcentrating hormone gene encodes an additional putative protein in a different reading frame. Endocrinology 137:4518-4521.

Verret L, Goutagny R, For P, Cagnon L, Salvert D, Leger L, Boissard R, Salin P, Peyron C, Luppi PH (2003) A role of melanin-concentrating hormone producing neurons in the central regulation of paradoxical sleep BMC. Neuroscience 4:19.

Yang XW, Model P, Heintz N (1997) Homologous recombination based modification in Escherichia coli and germline transmission in transgenic mice of a bacterial artificial chromosome. Nat Biotechnol 15:859-866.

Yoshizawa T, Yamagishi Y, Koseki N, Goto J, Yoshida H, Shibasaki F, Shoji S, Kanazawa I (2000) Cell cycle arrest enhances the in vitro cellular toxicity of the truncated Machado-Joseph disease gene product with an expanded polyglutamine stretch. Hum Mol Genet 9:69-78.

Zamir N, Skofitsch G, Jacobowitz (1986) DM distribution of immunoreactive melanin-concentrating hormone in the central nervous system of the rat. Brain Res 373:240-245. 